\title{
Dissipation of Mefenacet and Pretilachlor in Paddy Soils under Laboratory Oxidative and Reductive Conditions*
}

\author{
Ferdinand F. Fajardo ${ }^{* *, * * *}$, Kazuhiro Takagi ${ }^{* * * *}$ and Kenji Usui**
}

Key words: aerobic, anaerobic, microbial factor, mefenacet, pretilachlor

キーワード: 好気的, 嫌気的, 微生物要因, メフェ ナセット,プレチラルロール

Mefenacet [2-(benzothiazo1-2-yloxy) - N methylacetanilide $]^{2)}$ and pretilachlor [2chloro-2', 6'-diethyl-N-(2-propoxyethyl) acetanilide ${ }^{5)}$ are both highly selective herbicides used in paddy rice and very popular in Japan. Both of them belong to class amides which are used as pre-emergent or pre-plant soil incorporated herbicides ${ }^{2,6}$. Mefenacet is strongly adsorbed in soil ${ }^{12)}$ and its half-life is reported to be about 10 days in alluvial soil and 180 days in volcanic soils ${ }^{13}$. Pretilachlor, a chloroacetanilide, is reported to have a half -life of 2-20 days in the field and 6-20 days in the laboratory ${ }^{5}$. Currently, only a handful of studies dealing with the dissipation or degradation of mefenacet and pretilachlor under

\footnotetext{
* Parts of this paper were presented at the 16 th Asian -Pacific Weed Science Society Conference held at Kuala Lumpur, Malaysia, 1997 and at the 9th International Congress of Pesticide Chemistry held in London, UK, 1998

**Institute of Applied Biochemistry, University of Tsukuba, Tsukuba, Ibaraki, 305-8572, Japan ***Present : De La Salle University, Philippines

****Herbicide Chemistry Laboratory, National Institute of Agro-Environmental Sciences, Tsukuba, Ibaraki, 305-8604, Japan

フェルディナンド F.ファハルド**・高木和広***・臼井健

二**: 実験室酸化還元条件における水田土壤中でのメフ

エナセットとプレチラルロールの消失

** 筑波大学応用生物化学系

****農業環境技術研究所

(Received September 24, 1999 : Accepted September $20,2000)$
}

lowland conditions have been reported in $\operatorname{Japan}^{10,11)}$. It was therefore the aim of this study to elucidate the major path of dissipation of mefenacet and pretilachlor in paddy soil under laboratory conditions. The experiments were subdivided into oxidative and reductive under autoclaved and non-autoclaved conditions to determine the role of microbes in the dissipation of the two herbicides.

\section{Materials and Methods}

\section{(1) Experimental setup}

Soils were collected from the experimental field of the National Institute of Agro-Environmental Sciences (NIAES) in Kannondai, Tsukuba-shi (alluvial soil with $46.7 \%$ sand; $19.4 \%$ silt; $33.9 \%$ clay; $\mathrm{MWHC}=57.5 \% ; \mathrm{pH}=$ 5.2 (in water); $1.83 \%$ organic carbon; total $\mathrm{N}=0.15 \% ; \mathrm{CEC}=122 \mathrm{mmol} / \mathrm{kg}$ ). Fifteen $\mathrm{kg}$ of a soil was taken at $0-15 \mathrm{~cm}$ depth, air dried, and sieved using $2 \mathrm{~mm}$ mesh, moisture adjusted to about $20 \%$, then stored at $4^{\circ} \mathrm{C}$ until ready for use. Soils were taken from plots that had not beeen treated with any herbicides. Soils used in the 1996 and 1997 experiments were collected in November 1995 while those used in 1998 were collected in November 1997.

For the oxidative experiments, $300 \mathrm{~g}$ of fresh soil was pre-incubated in the dark for 5 -7 days at $25^{\circ} \mathrm{C}$ and then used for the dissipation tests. For the reductive experiments, about $300 \mathrm{~g}$ of fresh soil mixed with $250 \mathrm{ml}$ of distilled water in a $500 \mathrm{ml}$ glass jar was pre- 
incubated in the dark for 1-1.5 months at $25^{\circ} \mathrm{C}$. When the soil Eh below $1 \mathrm{~cm}$ was -150 $\mathrm{mv}$ or less, the water layer and the top $1 \mathrm{~cm}$ of soil layer were removed. Soil $\mathrm{Eh}$ was maintained between -150 to $-250 \mathrm{mv}$ because it corresponded to the anaerobic condition under actual field situations. Soil Eh was measured on each sampling day. Under an oxidative condition, soil Eh never reached or came near the reductive condition $^{3,10,11)}$.

In both oxidative- and reductive-autoclaved experiments, soils were autoclaved twice at a $24-\mathrm{hr}$ interval at $121^{\circ} \mathrm{C}, 1.05 \mathrm{~kg} / \mathrm{cm}^{2}$ for 15 min each time.

For the dissipation tests, incubation was carried out for $7,14,21,28$ and 42 days at $22^{\circ} \mathrm{C}$ under a dark condition.

A. Oxidative-non-autoclaved soil experiment

Fifteen $\mathrm{g}$ of pre-incubated soil was mixed with $55 \mathrm{ml}$ distilled water in $200 \mathrm{ml}$ glass jars. The resultant mixture was a layer of about 1 $\mathrm{cm}$ soil and $2 \mathrm{~cm}$ water. Pretilachlor (98\% purity) and mefenacet (99\% purity) were applied at $5 \mu \mathrm{g} / \mathrm{g}$ dry soil and $10 \mu \mathrm{g} / \mathrm{g}$ dry soil, respectively. The applied soils were then stirred thoroughly, the original weight determined, and placed in an incubator. At each sampling time, the gross weight of the sample was adjusted to the original by adding appropriate amounts of distilled water.

B. Oxidative-autoclaved soil experiment

A similar procedure was followed except that all materials were autoclaved and all operations were carried out in a sterile room. C. Reductive-non-autoclaved soil experiment

The pre-incubated reductive soil (below the $1 \mathrm{~cm}$ layer) was treated with $0.5 \mu \mathrm{g} / \mathrm{g}$ dry soil of either herbicide. Then, $25 \mathrm{~g}$ of each soil (fresh weight) was put in a $50 \mathrm{ml}$ glass cylinder (Nichiden SV-50), and placed inside a tightly lidded desiccation jar. The inner jar condition was kept reductive by placing 4 packets of BBL ${ }^{\circledR}$ Gas Pak ${ }^{\circledR}$ and Gas Pak catalyst ${ }^{\circledR}$ (Becton Dickinson Co.) in each jar. On each sampling day, the moisture of the sample was adjusted to the original to maintain a water saturated condition by adding autoclaved-distilled water, and the used $\mathrm{BBL}{ }^{\circledR}$ anaerobic system kits were replaced with fresh ones.

D. Reductive-autoclaved soil experiment

A similar procedure to that in experiment $\mathrm{C}$ was followed except that, after preincubation the soil was autoclaved and all operations were carried out in a sterile room.

\section{(2) Herbicide extraction and analysis}

The same procedure of herbicide extraction and GC analysis as used in the field trials $^{3)}$ was used in these experiments ${ }^{6}$. Twenty $g$ of incubated soil was extracted twice with two $50 \mathrm{ml}$ portions of acetone. After the acetone in the filtrate of the mixture had evaporated, the moist residue was extracted and separated with $30 \mathrm{ml}$ hexane and $30 \mathrm{ml}$ of $5 \% \mathrm{NaCl}$ solution. The herbicide -hexane layer was then evaporated to dryness and re-dissolved with 5-20 $\mathrm{ml}$ acetone.

Percentage recoveries, using this procedure, were $89.8 \%$ (S.D. $=3 \%, \mathrm{n}=3$ ) and $96.9 \%$ (S.D. $=3 \%, \mathrm{n}=3$ ) for pretilachlor and mefenacet, respectively.

\section{(3) Data analysis}

The half-life and dissipation rates were calculated using the simple first order kinetics $(\mathrm{SFOK})^{11)}$ equation $\mathrm{C}=\mathrm{C}_{0} \mathrm{e}^{-\mathrm{kt}}$, where $\mathrm{C}$ is the amount of herbicide ( $\mathrm{mg} \mathrm{kg}^{-1}$ soil) at time $\mathrm{t}$; $\mathrm{C}_{0}$ is the amount of herbicide $\left(\mathrm{mg} \mathrm{kg}^{-1}\right.$ soil) at time $0 ; \mathrm{k}$ is rate constant $\left(\mathrm{day}^{-1}\right)$ of dissipation and $t$ is time (day). The dissipation rate constant $(\mathrm{k})$ was calculated by linear regression from the transformed firstorder rate equation, $\ln \mathrm{C}=\ln \mathrm{C}_{0}-\mathrm{kt}$. Half life $\left(\mathrm{DT}_{50}\right)$ was calculated using the equation 
$-\ln (0.5) / \mathrm{k}$. All experiments were done twice with two replications per treatment.

\section{Results and Discussion}

The oxidative condition in the experiment was an estimation of the $0-1 \mathrm{~cm}$ layer under actual field conditions ${ }^{10,11}$. Similarly, the reductive soil experiment was an estimation of the anaerobic or reductive layer under lowland field conditions ${ }^{10,11)}$.

Figure 1 shows the dissipation of mefenacet and pretilachlor in paddy soil under reductive and oxidative conditions in the laboratory. For mefenacet, under oxidative/autoclaved conditions, dissipation was stagnant from the 7 th day on. Under oxidative/non-autoclaved conditions, a continuous linear decrease was observed. Under reductive condition, autoclaved soils showed no sign of active dissipation while the nonautoclaved soils dissipated rapidly in a cur-
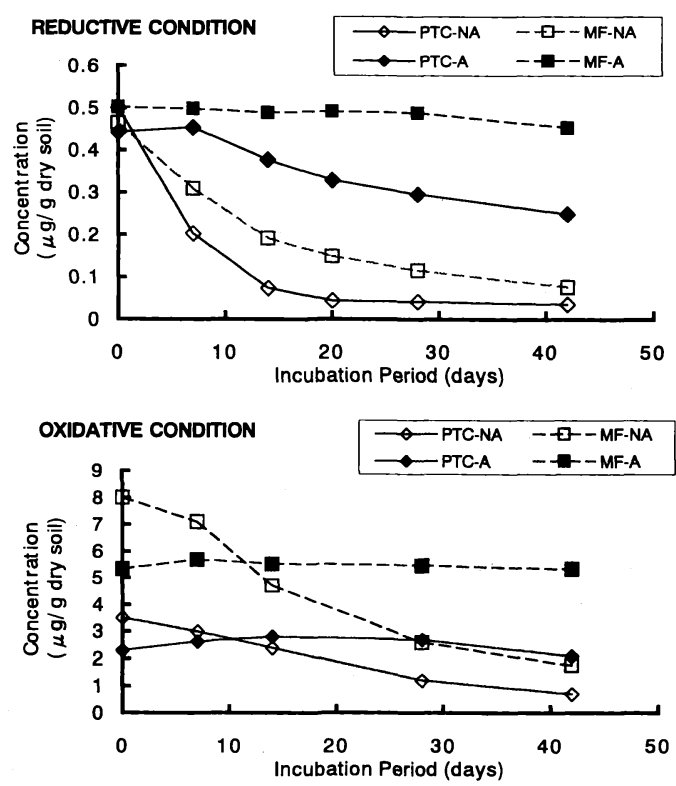

Fig. 1 Mefenacet (MF) and pretilachlor (PTC) dissipation in the laboratory under oxidative or reductive conditions. ( $\mathrm{A}=$ autoclaved soil; $\mathrm{NA}=$ non-autoclaved soil) vilinear pattern.

For pretilachlor, under oxidative condition, dissipation in autoclaved soils appeared to be stagnant while that in the non-autoclaved was observed to be a continuous linear decrease until 42 days. Under reductive/autoclaved condition, pretilachlor dissipated in a gradually decreasing trend. Under reductive/ non-autoclaved condition, pretilachlor dissipation was curvilinear and was quick from 0 to about 3 weeks. Dissipation in non-autoclaved soils was much faster compared to autoclaved soils.

The dissipation pattern of pretilachlor in non-autoclaved soil indicated a faster dissipation rate than mefenacet, especially under reductive condition.

For both herbicides, comparison of the dissipation in the non-autoclaved and autoclaved soils strongly suggests that microbial transformation or degradation ${ }^{4,7,8)}$ plays an important role. The dissipation pattern of pretilachlor in reductive/autoclaved soils, however, showed a difference from mefenacet. Mefenacet dissipation was almost absent while pretilachlor dissipated considerably from one week onward. This suggests that loss of pesticide due to soil microbes ${ }^{1)}$ was not the only factor that affected the dissipation of pretilachlor. Reductive dehalogenation ${ }^{4,7,8)}$ might be one process by which pretilachlor had dissipated in the anaerobic soil layer.

The use of SFOK for estimating the halflives of both herbicides appeared sufficient as indicated by the high $\mathrm{R}^{2}$ values (Table 1 ). Under oxidative/non-autoclaved settings, half-lives of pretilachlor and mefenacet were about 11 and 16 days, respectively. Under oxidative/autoclaved condition, mefenacet dissipation was almost undetectable, while pretilachlor dissipated slowly in an almost linear manner with a half-life of 45 days. 
Table 1. Computed half-lives, degradation rates and $\mathrm{R}^{2}$ values for pretilachlor and mefenacet in non-autoclaved and autoclaved soil under reductive and oxidative conditions.

\begin{tabular}{ccccccc}
\hline $\begin{array}{c}\text { Soil } \\
\text { Condition }\end{array}$ & $\begin{array}{c}\text { Degradation } \\
\text { Rate }\left(\text { day }^{-1}\right)\end{array}$ & $\mathrm{R}^{2}$ & $\begin{array}{c}\text { Half-life } \\
\text { (days) }\end{array}$ & $\begin{array}{c}\text { Degradation } \\
\left.\text { Rate (day }{ }^{-1}\right)\end{array}$ & $\mathrm{R}^{2}$ & $\begin{array}{c}\text { Half-life } \\
(\text { days })\end{array}$ \\
\hline Oxidative & \multicolumn{2}{c}{ Pretilachlor (non-autoclaved) } & \multicolumn{2}{c}{ Pretilachlor (autoclaved) } \\
Reductive & 0.0399 & 0.9539 & 16.0 & 0.0026 & 0.3171 & 223.6 \\
& 0.0615 & 0.7809 & 11.3 & 0.0154 & 0.9609 & 45.0 \\
Oxidative & \multicolumn{2}{c}{ Mefenacet (non-autoclaved) } & \multicolumn{2}{c}{ Mefenacet (autoclaved) } \\
Reductive & 0.0296 & 0.9725 & 17.8 & 0.0034 & 0.2348 & 577.6 \\
\hline
\end{tabular}

The half-life of pretilachlor under reductive/non-autoclaved soil corresponded to a relatively low $R^{2}$ value which might indicate that a more complex model ${ }^{10)}$ could be better for estimating its half-life. Using the biphasic first order kinetics, i.e., two SFOK were used to describe the half-life, the half-life of pretilachlor was 5.7 days for the first phase (0-21 days, $\mathrm{R}^{2}=0.9978$, dissipation rate $=0.1214 /$ day) and 96.7 days for the second phase (21-42 days, $\mathrm{R}^{2}=0.8983$, dissipation rate $=0.0074 /$ day).

The results of this study suggest that mefenacet dissipation in both aerobic and anaerobic soil condition is largely affected by microbial factors. For pretilachlor, dissipation through microbial transformation was evident in the oxidative soil layer, and in the reductive soil condition other avenues of dissipation, in addition to microbial transformation, seemed to take place.

Future elucidation studies need to be done on this aspect, especially the quantitative as well as qualitative isolation and identification of soil microbes. The determination of the herbicide metabolites and confirmation of dehalogenation as an avenue of dissipation, particularly for chlorinated herbicides such as pretilachlor, also need to be given attention.

\section{References}

1) Alexander, M. 1997. Biodegradation and Bioremediation. 2nd edition. Academic Press, California, USA. pp. 157-176.

2 ) Aya, M., K. Yasui, K. Kurihara, A. Kamochi and L. Eue. 1987. Proc. 10th Asian-Pacific Weed Sci. Soc. Conf. 567-573.

3 ) Fajardo, F. F., K. Takagi, M. Ishizaka and K. Usui. 1997. Proc. 16th Asian-Pacific Weed Sci. Soc. Conf. 148-152.

4) Kaufman, D. D. and P. C. Kearney. 1976. Herbicides: Physiology, Biochemistry, Ecology. 2nd edition" ed. by L. J. Audus, Academic Press, California, USA. pp. 29-64.

5 ) Murakami, S. and H. Hasegawa. 1993. Weed Res., Japan 38(4), 316-317. [in Japanese]

6 ) Murakami, S. and L. Ebner. 1983. Proc. 9th Asian -Pacific Weed Sci. Soc. Conf. 532-538.

7 ) Roberts, T. R. 1998. Metabolic pathways of agrochemicals. The Royal Society of Chemistry, Cambridge, UK. pp. 179-218.

8 ) Scheunert, I. 1992. Chemistry of Plant Protection, ed. by W. Ebing. Springer-Verlag, Heidelberg, Germany. pp. 23-75.

9 ) Srivastava, A., and K. Gupta. 1994. J. Pestic. Sci., 19: 145-149.

10) Takagi, K., F. F. Fajardo, K. Inao and $Y$. Kitamura. 1998. Rev. Toxicol., 2, 269-286.

11) Takagi, K., K. Inao and Y. Kitamura. 1996. Proc. 14th Symposium on Environ. Sci. Pestic. pp. 6580. [in Japanese]

12) Tomlin, C. (ed.) 1997. The Pesticide Manual. 11th edition. British Crop Protection Council and The Royal Society of Chemistry, U K. pp. 779-781.

13) Walker, A., and S. J. Welch. 1991. Weed Res., 31, 49-57. 